\title{
Continuous positive airway pressure breathing in the postoperative management of the cardiac infant
}

\author{
A. D. CRE W, P. I. VARKON Y I ${ }^{1}, L . G . G A R D R^{2}{ }^{2}$, \\ Q. L. A. ROBINSON${ }^{3}, E$. W A L L, and P. B. DEVERALL \\ Leeds Regional Thoracic Surgical Centre, Killingbeck Hospital, Leeds LS14 6UQ
}

\begin{abstract}
Crew, A. D., Varkonyi, P. I., Gardner, L. G., Robinson, Q. L. A., Wall, E., and Deverall, P. B. (1974). Thorax, 29, 437-445. Continuous positive airway pressure breathing in the postoperative management of the cardiac infant. Continuous positive airway pressure with spontaneous ventilation was used in the postoperative period following palliative or corrective surgery for congenital heart defects in a group of children of less than 3 years of age. After stabilization of the cardiovascular state, continuous positive airway pressure breathing (CPAP) was shown to be a suitable alternative to continuous positive pressure ventilation (CPPV). A statistically significant increase in $\mathrm{PaO}_{2}$ was observed on changing from CPPV to CPAP. A statistically significant decrease in $\mathrm{PaO}_{2}$ and increase in pulmonary venous admixture was observed after discontinuing the positive airway pressure and allowing the patient to breathe at ambient pressure.

We would recommend CPAP as an intermediate manoeuvre in the withdrawal of ventilatory support as it introduces a smoothness and stability into patient management régimes which was previously lacking. Careful selection of apparatus is necessary as the airway pressure should be truly continuous and steady.

In neonates the dead space of the system should be reduced to a minimum; CPAP alternating with periods on CPPV may be necessary for some time after cardiovascular stability has been attained.
\end{abstract}

Cardiac operations in children under 3 years of age are now frequently performed. Pulmonary dysfunction may be present before operation (Lees, Way, and Ross, 1967; Lees, Burnell, Morgan, and Ross, 1968; Howlett, 1972) and anatomical factors may be implicated (Stanger, Lucas, and Edward, 1969). Postoperative pulmonary dysfunction is common and can be a significant factor determining the postoperative course (Downes, Nicodemus, Pierce, and Waldhausen, 1970).

There are several disadvantages inherent in the use of ventilators which may add to the problems of overall management (Daily and Northway, 1971) apart from those associated with prolonged endotracheal intubation. Spontaneous respiration out of phase with a ventilator may cause fluctuations of intrapulmonary pressure having a detrimental effect on cardiac and pulmonary function. The prolonged use of a ventilator may cause

'Orszagos Kardiologiai Intezet, Budapest

'The General Infirmary, Leeds

Otley General Hospital irreversible changes in the pulmonary parenchyma (Barnes, Glover, Hull, and Milner, 1969; Banerjee, Girling, and Wigglesworth, 1972).

A personal communication, later reported (Stewart, Edmunds, Kirklin, and Allarde, 1973), on the beneficial effects of continuous positive airway pressure breathing (CPAP) after cardiac surgery made us aware of the potential value of this technique.

The present report is an attempt to compare our clinical criteria for the use of CPAP with its effect on pulmonary venous admixture and arterial oxygen tension, and to assess its value as an alternative to continuous positive pressure ventilation (CPPV).

\section{MATERIALS AND METHODS}

SELECTION OF PATIENTS Children under 3 years of age requiring postoperative ventilation of the lungs following cardiac surgery or cardiac catheterization were considered (Table I).

More detailed investigations were undertaken in 


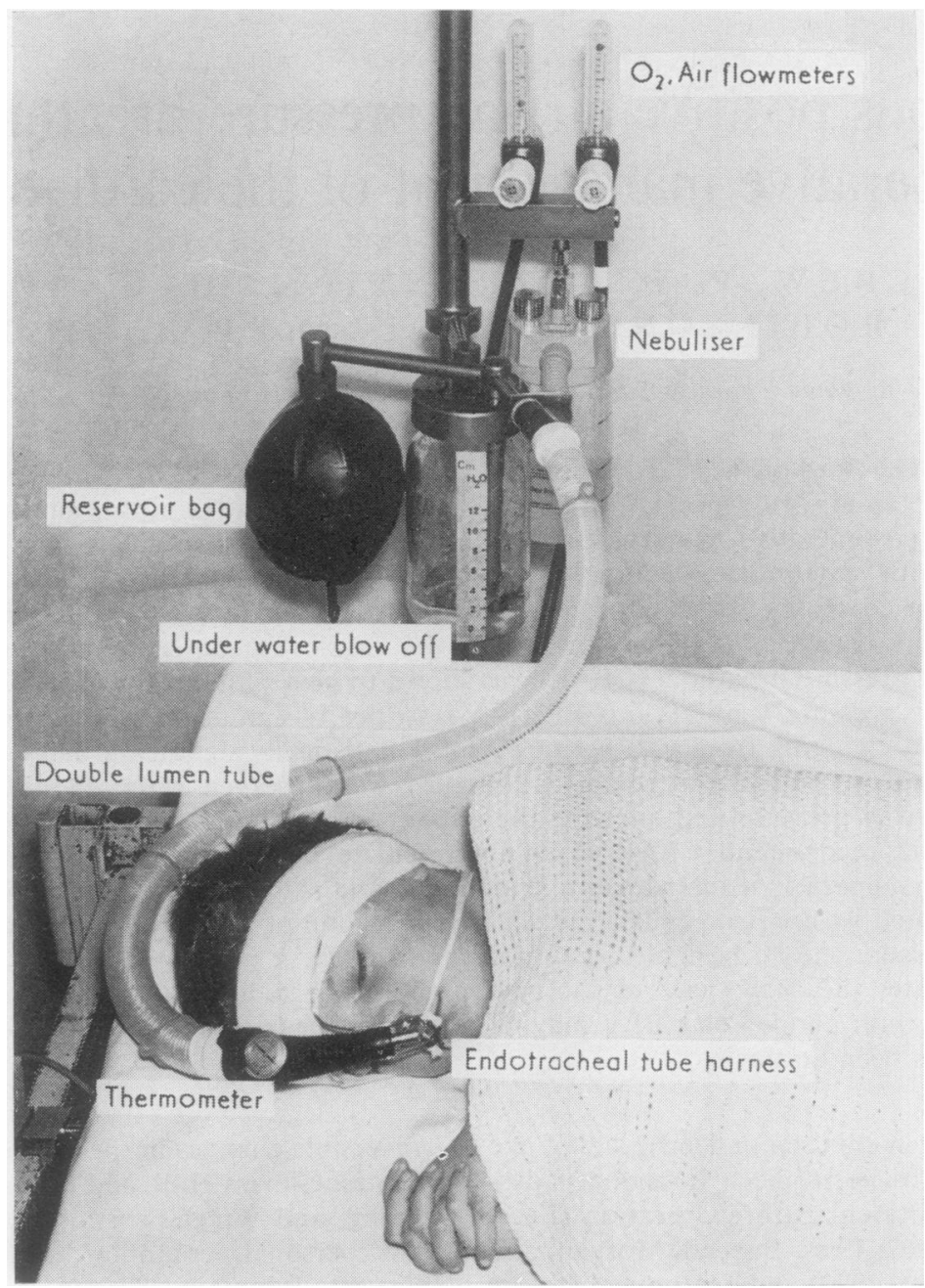

FIG. 1. CPAP in use in the postoperative management of a 4-year-old boy following total correction of Fallot's tetralogy.

seven patients, the presence of an intracardiac shunt having been excluded at the time of operation, using a dye-dilution technique. They were omitted in 11 because either an intracardiac shunt was present, which would have invalidated the arterial oxygen tension results, or suitable intravascular sampling points were not available. There was no other selection of patients.

MANAGEMENT OF CPPV Each patient who had undergone an open intracardiac procedure was ventilated with an oxygen-air-nitrous oxide mixture containing not more than $50 \%$ nitrous oxide or $70 \%$ oxygen. The nitrous oxide was continued for an average of 12
(2-32) hours. Only one of the patients undergoing $a$ closed palliative operation required nitrous oxide $\mathrm{N}$ Thereafter ventilatory control was established, wher necessary, with repeated small intravenous doses of sedative (diazepam or phenobarbitone).

Attempts were made to bring the arterial carbon? dioxide tension towards the normal physiological ranges while still maintaining ventilatory control and the absence of significant respiratory effort. The latter was assessed by the patient's ability to alter the inflation pressures and minute volumes. Table II shows tha? these adjustments were inadequate in the majority of patients. An end-expiratory positive pressure, in the range of $3-5 \mathrm{~cm}$ water, was maintained during the 
T A B L E I

BASIC CLINICAL DETAILS, GROUPED CONVENIENTLY ACCORDING TO PROCEDURE AND AGE

\begin{tabular}{|c|c|c|c|}
\hline $\begin{array}{l}\text { Reference } \\
\text { Number }\end{array}$ & Age & Diagnosis & Procedure \\
\hline $\begin{array}{l}1 \\
2 \\
3 \\
4 \\
5\end{array}$ & $\begin{array}{l}7 \text { days } \\
4 \text { mth } \\
1 \text { mth } \\
7 \text { days } \\
2 \text { days }\end{array}$ & $\begin{array}{l}\text { TGA, tricuspid atresiat } \\
\text { TGA, VSD, PDA, coarctationt } \\
\text { Multiple VSD, congestive cardiac failure } \\
\text { Pulmonary atresia, intact ventricular septum } \\
\text { Pulmonary atresia, intact ventricular septum }\end{array}$ & $\begin{array}{l}\text { Cardiac catheterization } \\
\text { Palliative operation, residual intracardiac shunt } \\
\text { Palliative operation, residual intracardiac shunt } \\
\text { Palliative operation, residual shunt } \\
\text { Palliative operation, residual shunt }\end{array}$ \\
\hline $\begin{array}{l}6 \\
(7) \\
(8) \\
(9) \\
10 \\
(11) \\
(12) \\
13 \\
14 \\
(15) \\
16 \\
17 \\
(18)\end{array}$ & $\begin{array}{l}7 \text { days } \\
4 \mathrm{mth} \\
5 \mathrm{mth} \\
12 \mathrm{mth} \\
12 \mathrm{mth} \\
13 \mathrm{mth} \\
15 \mathrm{mth} \\
20 \mathrm{mth} \\
24 \mathrm{mth} \\
28 \mathrm{mth} \\
30 \mathrm{mth} \\
33 \mathrm{mth} \\
34 \mathrm{mth}\end{array}$ & $\begin{array}{l}\text { TAPVC } \\
\text { TAPVC } \\
\text { PS, ASD! } \\
\text { TGA } \\
\text { VSD } \\
\text { Atrioventricular canal } \\
\text { Fallot } \\
\text { VSD } \\
\text { VSD } \\
\text { VSD } \\
\text { Fallot } \\
\text { TGA } \\
\text { VSD }\end{array}$ & $\begin{array}{l}\text { *Correction } \\
\text { *Correction } \\
\text { *Correction } \\
\text { * Mustard procedure } \\
\text { * Correction, small residual shunt } \\
\text { * Correction, slight residual mitral incompetence } \\
\text { * Correction } \\
\text { *Correction } \\
\text { "Correction } \\
\text { "Correction } \\
\text { "Correction } \\
\text { * Mustard procedure } \\
\text { "Correction }\end{array}$ \\
\hline
\end{tabular}

* Use of an open intracardiac technique and a bubble oxygenator.

\section{+ Mortality.}

() Patients selected for further investigation.

ASD - atrial septal defect; PDA - patent ductus arteriosus; PS - pulmonary stenosis; TGA - transposition of the great arteries; TAPVC - total anomalous pulmonary venous connection; VSD - ventricular septal defect.

T A B L E I I

OBSERVATIONS ON CLINICAL COURSE OF PATIENTS ON CPAP

\begin{tabular}{|c|c|c|c|c|c|c|c|}
\hline $\begin{array}{l}\text { Reference } \\
\text { Number }\end{array}$ & $\begin{array}{c}2 \\
\text { Termination of CPAP and Subsequent Events }\end{array}$ & $\begin{array}{c}3 \\
\text { Period } \\
\text { of } \\
\text { CPPV } \\
\text { (hr) }\end{array}$ & $\begin{array}{c}4 \\
\text { Period } \\
\text { of } \\
\text { Success- } \\
\text { ful } \\
\text { CPAP } \\
\text { (hr) }\end{array}$ & $\begin{array}{c}5 \\
\text { Period } \\
\text { after } \\
\text { CPAP to } \\
\text { Extuba- } \\
\text { tion } \\
\text { (hr) }\end{array}$ & $\begin{array}{c}6 \\
\text { Final } \\
\mathrm{PaCO}_{2} \\
\text { on } \\
\text { CPPV } \\
\text { (mmHg) }\end{array}$ & $\begin{array}{c}7 \\
\text { Paco, } \\
\text { after } \\
2 \mathrm{hr} \\
\underset{\text { (mAP }}{\mathrm{CPH}}\end{array}$ & $\begin{array}{c}8 \\
\text { Max. } \\
\text { PaCO, }_{2} \\
\text { on } \\
\text { CPAP } \\
(\mathrm{mmHg})\end{array}$ \\
\hline $1+$ & Inoperable, support withdrawn & (7) & (18) & & & & \\
\hline $\begin{array}{l}2 \dagger \\
3 \\
4^{*} \\
5^{*}\end{array}$ & $\begin{array}{l}\text { Successful CPAP early discontinuation may be } \\
\text { implicated in death } \\
\text { Extubated } \\
\text { Extubated } \\
\text { Extubated }\end{array}$ & $\begin{array}{r}2 \\
3 \\
79 \\
46\end{array}$ & $\begin{array}{l}22 \\
15 \\
18 \\
45\end{array}$ & $\begin{array}{r}1 \\
1 \\
22 \\
4\end{array}$ & $\begin{array}{l}29 \cdot 5 \\
25 \\
25 \cdot 7 \\
49\end{array}$ & $\begin{array}{l}35 \\
28 \\
44 \\
39 \cdot 5\end{array}$ & $\begin{array}{l}35 \\
31 \cdot 5 \\
56 \\
52\end{array}$ \\
\hline \multirow[t]{2}{*}{$\begin{array}{l}6^{*} \\
7 \\
8 \dagger \\
9 \\
10 \\
11 \\
12 \\
13 \\
14 \\
15 \\
16 \\
17 \\
18\end{array}$} & $\begin{array}{l}\text { Extubated } \\
\text { Extubated } \\
\text { Re-thoracotomy, CPAP not implicated } \\
\text { Re-thoracotomy, CPAP not implicated, tamponade } \\
\text { Extubated } \\
\text { Re-thoracotomy, CPAP not implicated, haemorrhage } \\
\text { Extubated } \\
\text { Extubated } \\
\text { Extubated } \\
\text { Extubated } \\
\text { Extubated } \\
\text { Extubated } \\
\text { Extubated }\end{array}$ & $\begin{array}{r}106 \\
21 \\
16 \\
30 \\
3 \\
8 \\
21 \\
4 \\
15 \\
22 \\
4 \\
40 \\
24\end{array}$ & $\begin{array}{l}141 \\
96 \\
(10) \\
(19) \\
16 \\
(19) \\
98 \\
21 \\
34 \\
48 \\
85 \\
29 \\
28\end{array}$ & $\begin{array}{l}5 \\
2 \\
\\
3 \\
4 \\
4 \\
4 \\
2 \\
6 \\
7 \\
1\end{array}$ & $\begin{array}{l}42 \\
29 \\
30 \\
30 \\
26 \cdot 5 \\
27 \\
35 \\
34 \\
25 \cdot 3 \\
28 \\
33 \cdot 9 \\
29 \\
27\end{array}$ & $\begin{array}{l}49 \\
30 \\
34 \cdot 5 \\
31 \cdot 2 \\
38 \\
27 \cdot 5 \\
28 \cdot 5 \\
30 \\
28 \cdot 5 \\
28 \cdot 4 \\
37 \cdot 4 \\
28 \\
33\end{array}$ & $\begin{array}{l}64 \\
50 \\
36 \cdot 5 \\
36 \\
39 \\
47 \\
42 \\
42 \\
37 \\
40 \\
47 \\
34 \\
33\end{array}$ \\
\hline & $\begin{array}{l}\text { Mean } \\
\text { Standard deviation }\end{array}$ & 25 & 49 & $4 \cdot 7$ & $\begin{array}{r}30.9 \\
6.4\end{array}$ & $\begin{array}{r}33 \cdot 6 \\
6 \cdot 3 \\
\end{array}$ & $\begin{array}{r}42 \cdot 5 \\
9 \cdot 0 \\
\end{array}$ \\
\hline \multicolumn{2}{|c|}{$\begin{array}{l}\text { Significance of data from three neonates undergoing surgery (Nos. } 4 \text {, } \\
5,6) \text { compared with rest of those undergoing surgery (Nos. } 2,3,7 \\
\text { to 18) }\end{array}$} & $\begin{array}{l}\text { P<0.01 } \\
\text { Neonates } \\
\text { on CPPV } \\
\text { longer }\end{array}$ & $\begin{array}{l}\text { Not } \\
\text { sig- } \\
\text { nificant }\end{array}$ & $\begin{array}{l}\text { Not } \\
\text { sig- } \\
\text { nificant }\end{array}$ & $\begin{array}{l}\text { Not } \\
\text { sig- } \\
\text { nificant }\end{array}$ & $\begin{array}{l}\mathrm{P}<0.01 \\
\mathrm{PaCO}_{2} \text { on } \\
\mathrm{CPAP} \\
\text { higher in } \\
\text { neonates }\end{array}$ & $\begin{array}{l}\mathrm{P}<0.01 \\
\text { Max. } \\
\text { Paco, } \\
\text { higher in } \\
\text { neonates }\end{array}$ \\
\hline
\end{tabular}

* Neonates undergoing surgery; $\dagger$ mortality; ( ) figures not included in statistical comparisons. 
period of automatic ventilation of the lung. Optimal humidification was achieved with an ultrasonic nebulizer.

CARDIOVASCULAR STABILITY The trial of CPAP was begun when cardiovascular stability was attained. Table III presents the minimum or maximum limits which we consider to be satisfactory although these limits are often exceeded. The skin temperature was measured with a probe (Ellab H.3) lightly taped to the dorsum of the foot under a small cotton swab. The urine output was also taken into account.

Whether or not the patient required inotropic support did not affect our assessment of the stability of the cardiovascular state.

CONTINUOUS POSITIVE AIRWAY PRESSURE BREATHING A continuous positive airway pressure was produced by leading the expiratory limb of a modified T-piece circuit to an underwater blow-off (Fig. 2). The fresh gas flow rates were high enough to maintain a continuous blow-off, and therefore a steady positive airway pressure. The expiratory limb of the apparatus

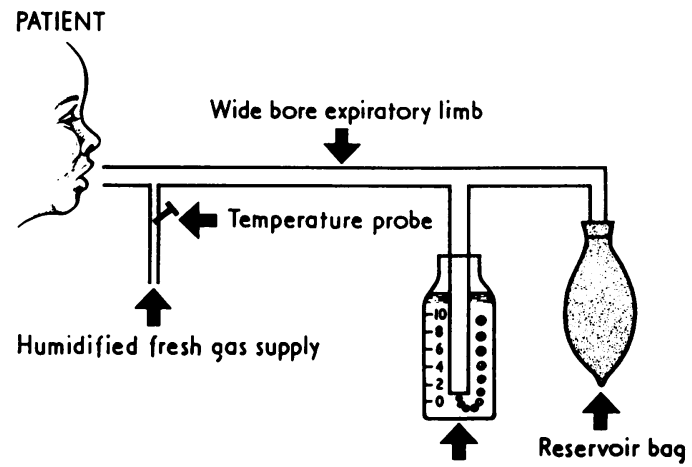

Water reservoir and blow off

FIG. 2. Diagrammatic representation of the CPAP system used in this investigation.

has a negligible resistance at the flows used (mean $19 \mathrm{l} / \mathrm{min} ; \mathrm{SD} \pm 4.51$.).

Breathing at ambient pressure occurs when the $\vec{\theta}$ reservoir bag is removed from the circuit.

T A B L E I I I

CLINICAL OBSERVATIONS ON WHICH AN ASSESSMENT OF 'CARDIOVASCULAR STABILITY' WAS MADE (Urine output and non-numerical observations are not included)

\begin{tabular}{|c|c|c|c|c|c|c|c|c|c|c|c|c|}
\hline \multirow[b]{2}{*}{$\begin{array}{c}\text { Reference } \\
\text { Number }\end{array}$} & \multicolumn{6}{|c|}{ Observations on CPPV immediately before starting CPAP } & \multicolumn{6}{|c|}{ Observations after Two Hours' CPAP } \\
\hline & $\begin{array}{l}\text { Arterial } \\
\text { Systolic } \\
\text { Pressure } \\
\text { (mmHg) }\end{array}$ & $\begin{array}{c}\text { Heart } \\
\text { Rate } \\
\text { (beats } \\
\text { per min) }\end{array}$ & $\underset{\substack{\text { Mean } \\
\text { (mmHg) }}}{\text { CVP }}$ & $\begin{array}{c}\text { Left } \\
\text { Atrial } \\
\text { Pressure } \\
\text { Mean } \\
\text { (mmHg) }\end{array}$ & $\begin{array}{l}\text { Skin } \\
\text { Temp. } \\
\text { Dorsum } \\
\text { Foot } \\
\left({ }^{\circ} \mathbf{C}\right)\end{array}$ & $\begin{array}{c}\text { Venti- } \\
\text { lator } \\
\text { Fre- } \\
\text { quency } \\
\text { (per min) }\end{array}$ & $\begin{array}{l}\text { Arterial } \\
\text { Systolic } \\
\text { Pressure } \\
(\mathrm{mmHg})\end{array}$ & $\begin{array}{c}\text { Heart } \\
\text { Rate } \\
\text { (beats } \\
\text { per min) }\end{array}$ & $\underset{\substack{\text { Mean } \\
(\mathrm{mmHg})}}{\text { CVP }}$ & $\begin{array}{c}\text { Left } \\
\text { Atrial } \\
\text { Pressure } \\
\text { Mean } \\
(\mathrm{mmHg})\end{array}$ & $\begin{array}{c}\text { Skin } \\
\text { Temp. } \\
\text { Dorsum } \\
\text { Foot } \\
\left({ }^{\circ} \mathrm{C}\right)\end{array}$ & $\begin{array}{l}\text { Fre- } \\
\text { quency } \\
\text { of Spon- } \\
\text { taneous } \\
\text { Breathing } \\
\text { (per min) }\end{array}$ \\
\hline $\begin{array}{l}1 * \dagger \\
2^{*} \dagger \\
3 \\
4 \dagger \\
5 \dagger\end{array}$ & $\begin{array}{r}90 \\
130 \\
80\end{array}$ & $\begin{array}{l}128 \\
135 \\
170 \\
100 \\
150\end{array}$ & & & & $\begin{array}{l}35 \\
20 \\
36 \\
32 \\
32\end{array}$ & $\begin{array}{r}110 \\
120 \\
90\end{array}$ & $\begin{array}{r}140 \\
130 \\
165 \\
96 \\
140\end{array}$ & & & $36^{5}$ & $\begin{array}{l}60 \\
40 \\
36 \\
55 \\
32\end{array}$ \\
\hline $\begin{array}{c}6 \dagger \\
(7) \\
(8)^{*} \\
(9) \\
10 \\
(11) \\
(12) \\
13 \\
14 \\
(15) \\
16 \\
17 \\
(18)\end{array}$ & $\begin{array}{r}80 \\
80 \\
90 \\
90 \\
105 \\
100 \\
95 \\
95 \\
115 \\
95 \\
115 \\
100 \\
100\end{array}$ & $\begin{array}{l}104 \\
160 \\
140 \\
178 \\
145 \\
110 \\
150 \\
150 \\
136 \\
140 \\
156 \\
110 \\
125\end{array}$ & $\begin{array}{r}10 \\
10 \\
6 \\
7 \\
14 \\
13 \\
10 \\
12\end{array}$ & $\begin{array}{r}12 \\
14 \\
18 \\
11 \\
9 \\
11 \\
6 \\
10 \\
14 \\
12 \\
7\end{array}$ & $\begin{array}{l}30 \\
35^{8} \\
36 \\
27^{2} \\
37 \\
35^{8} \\
36^{2} \\
36^{4} \\
30\end{array}$ & $\begin{array}{l}30 \\
30 \\
28 \\
25 \\
20 \\
20 \\
36 \\
26 \\
24 \\
26 \\
20 \\
22 \\
20\end{array}$ & $\begin{array}{r}85 \\
85 \\
110 \\
80 \\
105 \\
95 \\
105 \\
95 \\
100 \\
100 \\
115 \\
90 \\
100\end{array}$ & $\begin{array}{l}112 \\
170 \\
150 \\
144 \\
140 \\
135 \\
160 \\
138 \\
130 \\
145 \\
130 \\
110 \\
145\end{array}$ & $\begin{array}{r}10 \\
12 \\
5 \\
8 \\
14 \\
15 \\
9 \\
12\end{array}$ & $\begin{array}{r}19 \\
11 \\
10 \\
6 \\
10 \\
15 \\
10 \\
14 \\
11 \\
7\end{array}$ & $\begin{array}{l}34^{7} \\
27^{4} \\
37^{8} \\
37^{2} \\
\\
37\end{array}$ & $\begin{array}{l}38 \\
48 \\
46 \\
36 \\
60 \\
58 \\
38 \\
50 \\
42 \\
48 \\
48 \\
40 \\
40\end{array}$ \\
\hline $\begin{array}{l}\text { Min. } \\
\text { acceptable } \\
\text { level }\end{array}$ & 80 & & & & 30 & & $\varepsilon 0$ & & & & 30 & \\
\hline $\begin{array}{l}\text { Max. } \\
\text { acceptable } \\
\text { level }\end{array}$ & & 160 & 14 & 14 & & & & 160 & 14 & 14 & & 60 \\
\hline $\begin{array}{l}\% \text { of } \\
\text { Acceptable } \\
\text { observa- } \\
\text { tions }\end{array}$ & 100 & 89 & 100 & 91 & 89 & & 100 & 89 & 86 & 80 & 83 & 100 \\
\hline
\end{tabular}

Mortality.

() Patients selected for further investigation.

† Neonates. 
T A B L E I V

RESULTS FROM BLOOD SAMPLES TAKEN FROM SEVEN PATIENTS SELECTED FOR FURTHER STUDY

\begin{tabular}{|c|c|c|c|c|c|c|c|c|c|}
\hline \multirow[b]{2}{*}{$\begin{array}{l}\text { Reference } \\
\text { Number }\end{array}$} & \multicolumn{3}{|c|}{ Samples taken during CPPV } & \multicolumn{3}{|c|}{ Samples taken after $135 \mathrm{~min}$ CPAP } & \multicolumn{3}{|c|}{$\begin{array}{c}\text { Samples taken after } 15 \mathrm{~min} \\
\text { Breathing at Ambient Pressure }\end{array}$} \\
\hline & $\begin{array}{c}\text { Arterial } \\
\text { Oxygen } \\
\text { Tension } \\
\left(\mathrm{mmHg}^{2}\right) \\
\left(\mathrm{PaO}_{2}\right)\end{array}$ & $\begin{array}{c}\text { Arterio- } \\
\text { venous } \\
\text { Oxygen } \\
\text { Content } \\
\text { Diff. }(\mathrm{ml} \%) \\
\left(\mathrm{CaO}_{2}-\mathrm{CvO}_{2}\right)\end{array}$ & $\begin{array}{c}\text { Measured } \\
\text { Pulmonary } \\
\text { Venous } \\
\text { Admixture } \\
\text { as a } \\
\text { Ratio of } \\
\text { Total Flow }\end{array}$ & $\mathrm{PaO}_{2}$ etc. & $\begin{array}{l}\mathrm{CaO}_{2}-\mathrm{CvO}_{2} \\
\text { etc. }\end{array}$ & $\begin{array}{l}\text { Pul.-Ven. } \\
\text { Admixture } \\
\text { etc. }\end{array}$ & $\mathrm{PaO}_{2}$ etc. & $\begin{array}{l}\mathrm{CaO}_{2}-\mathrm{CvO}_{2} \\
\text { etc. }\end{array}$ & $\begin{array}{l}\text { Pul.-Ven. } \\
\text { Admixture } \\
\text { etc. }\end{array}$ \\
\hline $\begin{array}{r}7 \\
8 \\
9 \\
11 \\
12 \\
15 \\
18\end{array}$ & $\begin{array}{c}63 \cdot 1 \\
84 \cdot 35 \\
92 \cdot 9 \\
122 \cdot 9 \\
108 \cdot 0 \\
52 \cdot 0\end{array}$ & $\begin{array}{l}2 \cdot 60 \\
4 \cdot 28 \\
4 \cdot 41 \\
6 \cdot 19\end{array}$ & $\begin{array}{l}0 \cdot 3052 \\
0 \cdot 0885 \\
0 \cdot 1472 \\
0 \cdot 1315\end{array}$ & $\begin{array}{c}69 \cdot 0 \\
75 \cdot 3 \\
89 \cdot 4 \\
95 \cdot 73 \\
126 \cdot 5 \\
130 \cdot 5 \\
61 \cdot 0\end{array}$ & $\begin{array}{l}4 \cdot 92 \\
4 \cdot 39 \\
5 \cdot 86 \\
3.66 \\
6 \cdot 60\end{array}$ & $\begin{array}{l}0 \cdot 1946 \\
0 \cdot 1551 \\
0 \cdot 0868 \\
0 \cdot 1804 \\
0 \cdot 1125\end{array}$ & $\begin{array}{r}59 \cdot 0 \\
67 \cdot 0 \\
68 \cdot 3 \\
74 \cdot 6 \\
63 \cdot 8 \\
110 \cdot 7 \\
58 \cdot 5\end{array}$ & $\begin{array}{l}2 \cdot 56 \\
4 \cdot 31 \\
7 \cdot 57 \\
8 \cdot 07 \\
5 \cdot 01\end{array}$ & $\begin{array}{l}0 \cdot 3367 \\
0 \cdot 2379 \\
0 \cdot 1205 \\
0 \cdot 1890 \\
0 \cdot 1621\end{array}$ \\
\hline
\end{tabular}

The inspired gases were humidified by a heated nebulizer (Ohio), and by means of a double-lumen tube (Bushman and Robinson, 1968) administered to the patient at a temperature of $30-35^{\circ} \mathrm{C}$ and a relative humidity quoted as $96 \%$ at body temperature (Hayes and Robinson, 1970). The effective apparatus dead space is $5 \mathrm{ml}$ for the double-lumen tube and head harness combined.

BLOOD SAMPLING In those patients selected for further study (Table IV) simultaneous arterial and central venous samples were taken from a radial artery catheter and from a catheter placed with its tip in the superior vena cava or innominate vein. Although the venous sample so obtained is not true mixed venous blood, it is less subject to the errors due to streaming of blood that occurs in the right atrium and therefore indicates satisfactorily, within the limits of this study, the trends in mixed venous oxygen content.

The oxygen tension was measured within 5 minutes; the $\mathrm{pH}$ and carbon dioxide tension were measured within 15 minutes.

Haematocrit and haemoglobin estimations were made on the same blood sample before the investigation began. The blood haemoglobin was subsequently calculated from the haematocrit of the samples taken for blood gas estimations.

The inspired gas was taken from premixed cylinders of oxygen and nitrogen (BOC certificate of analysis). Nitrous oxide administration was discontinued a minimum of 30 minutes before the first blood sample (Sheffer, Steffenson, and Birch, 1972). The alveolar oxygen tension was estimated from the alveolar air equation, using an assumed respiratory quotient of $0 \cdot 8$ :

$$
\mathrm{PAO}_{2}=\mathrm{PIO}_{2}-\mathrm{PaCO}_{2}\left(\mathrm{FIO}_{2}+\frac{1-\mathrm{FIO}_{2}}{\mathrm{RQ}}\right)
$$

Oxygen content and pulmonary venous admixture were estimated from tables (Kelman and Nunn, 1968).

\section{STUDY}

Stage I When cardiovascular stability was attained, simultaneous arterial and venous samples were drawn after 10 minutes' administration of the premixed gases of known oxygen content via an Engstrom 300 ventilator. After this first sample, CPAP was immediately begun at a pressure of $8 \mathrm{~cm}$ water. After approximately $2 \frac{1}{4}$ hours on CPAP (120 to 148 minutes), the second blood samples were taken following $10 \mathrm{~min}-$ utes' administration of the premixed gases via the CPAP apparatus.

Stage II Immediately after this latter sample the positive airway pressure was discontinued. The inspired gases were taken from the premixed cylinders throughout this period. The third blood samples were drawn after 15 minutes' breathing at ambient pressure.

\section{RESULTS}

CLINICAL CPAP has been a suitable alternative to CPPV in every patient in this series, taking our criteria of cardiovascular stability as the point in time at which spontaneous ventilation should be considered. Table II presents our observations on the clinical course of patients in this investigation. Column 6 shows the final $\mathrm{PaCO}_{2}$ on CPPV and the limited success with which it was possible to control ventilation at arterial carbon dioxide tensions near to the normal range. After two hours spontaneous ventilation (col. 7) there was a small increase in average $\mathrm{PaCO}_{2}$ but no significant trend.

There was no notable trend in the measured parameters other than the respiratory frequency (Table III). The respiratory pattern and clinically assessed work of breathing was acceptable in all but one patient. In this patient (no. 4) alternating 
periods of CPAP and CPPV were necessary, despite a stable cardiovascular state, for 79 hours (col. 3, Table II). None of the three deaths in the series was associated with the use of CPAP. Two (Table I, Nos. 1 and 2) may have been associated with its premature withdrawal.

Even though the data are from a small population, Table II shows that there is evidence to suggest significant differences in the postoperative course of the neonate.

STUDY Table IV sets out the data obtained in the seven patients selected for further study.

Stage $I$ There is a statistically significant rise in arterial oxygen tension on CPAP (Fig. 3) with variable changes in the index of pulmonary venous admixture (Fig. 4).

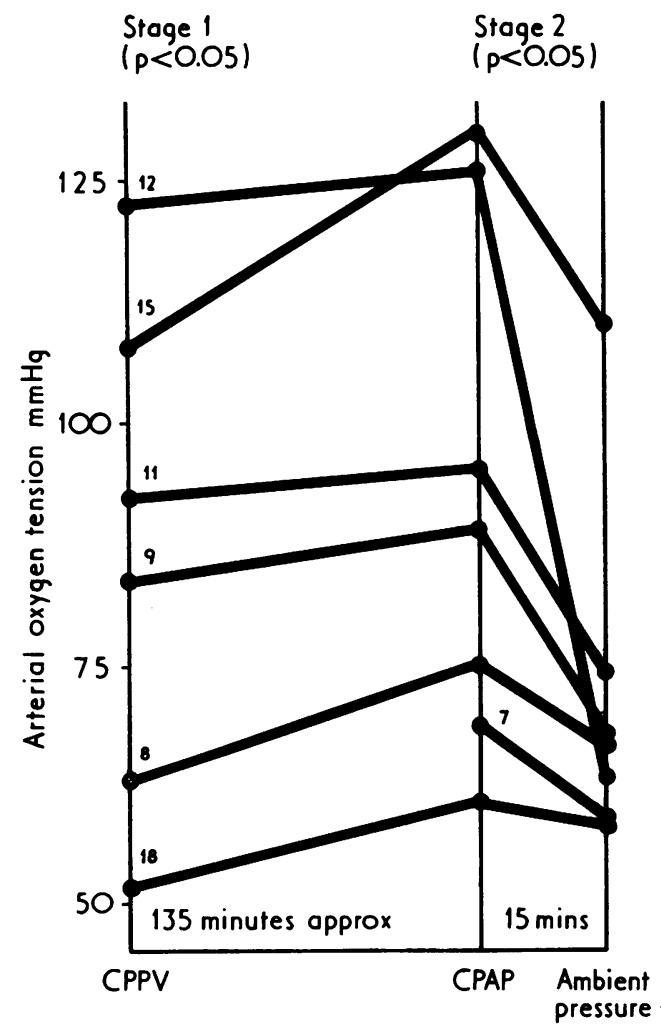

FIG. 3. Arterial oxygen tensions noted at each of the three ventilatory states of the investigation (CPPV, CPAP, spontaneous ventilation at ambient pressure). The numeral adjacent to each line is the patient identification number.

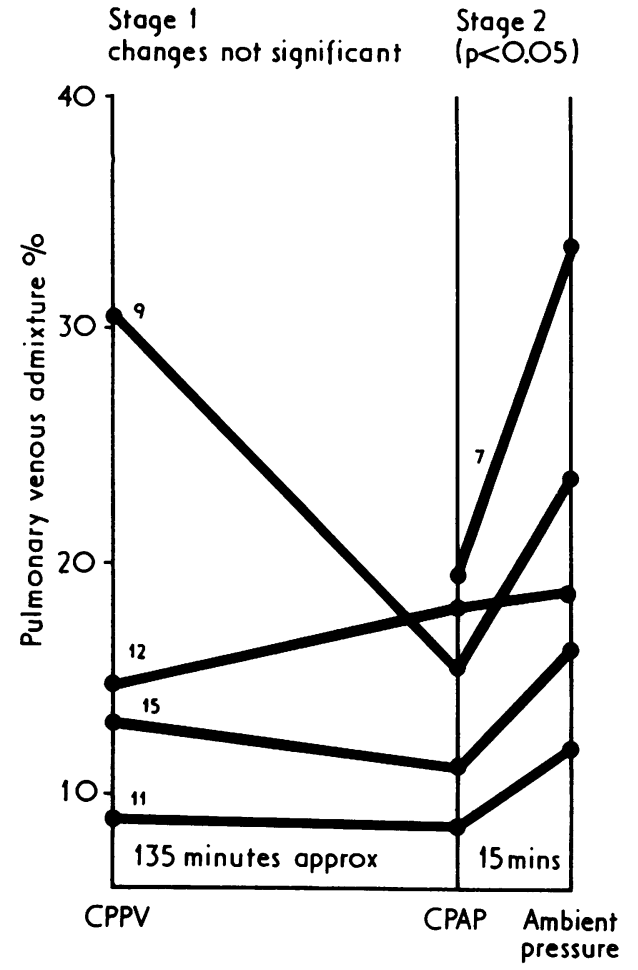

FIG. 4. Index of pulmonary venous admixture at each of the three ventilatory states of the investigation.

Stage II There are statistically significant changes in arterial oxygen tension (Fig. 3) which are in part explained in every case by an increase in the pulmonary venous admixture (Fig. 4). No trend is discernible in the arteriovenous oxygen content difference in either stage of the investigation (Fig. 5).

In four patients (Nos. $7,8,11,18$ ) the inspired gas had an oxygen content of $30 \%$, and in three patients (Nos. 9, 12, 15) of $40 \%$. Although some criticism may be directed at arterial oxygen tensions in some patients being below the acceptable normal range, nevertheless the trends in arterial oxygen tension and pulmonary venous admixture are significantly reproduced.

STATISTICAL METHODS The data in Table IV were compared using a paired Student's $t$ test. Comparison of the data in Table II, between the neonates and the remaining surgical group, was made with the Wilcoxon-Mann-Whitney nonparametric test. 


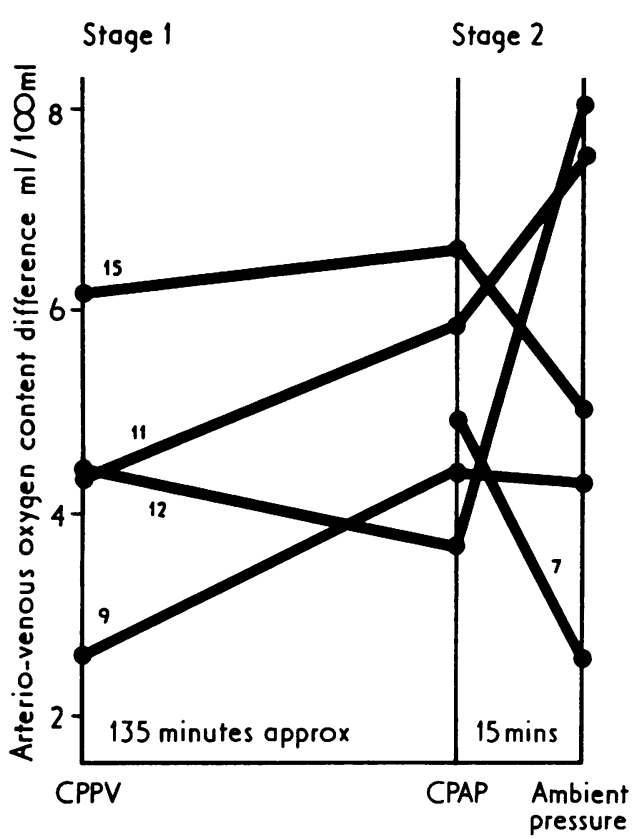

FIG. 5. Arteriovenous oxygen content difference at each of the three ventilatory states of the investigation.

\section{DISCUSSION}

The clinical features of postoperative pu!monary dysfunction may be summarized as an increase in respiratory frequency and a fall in arterial oxygen tension. There is frequently an increase in respiratory effort and accumulation of secretions within the bronchial tree. Its management has largely depended on the inhalation of humidified, oxygenenriched gas mixtures and in certain circumstances the use of automatic ventilation of the lungs. The technical problems and specific disadvantages associated with the use of mechanical ventilators have been well recognized. Some of these difficulties may be overcome by the efficient fixation of the endotracheal tube (Crew, Wall, and Wright, 1971) and the ultrasonic humidification of the inspired gas.

The problem then is to discontinue ventilatory support at the earliest opportunity compatible with continued cardiovascular stability and adequate respiratory function. Restlessness in the face of respiratory inadequacy is common and will still further add to the body's oxygen needs. The control of ventilation and the process of weaning a child from a ventilator have however remained difficult problems.

Weaning may take weeks in the presence of established lung disease (Gregory, 1972), and marked falls in arterial oxygen tension are common when spontaneous breathing at ambient pressure is begun. Hitherto we have not found it possible to wean the younger patients directly to spontaneous breathing without an intermediate phase in which CPPV was interrupted by progressively lengthening periods of spontaneous breathing at ambient pressure. Particularly in infants this period of postoperative management was of ten unstable and not satisfactory.

CPAP has helped in the management of children after major cardiac surgery (Haller et al., 1973; Stewart et al., 1973). It may adversely affect the cardiac output, especially in the presence of a normal lung compliance. However, adjustments to the central venous pressure by blood volume expansion is part of the postoperative régime following cardiac surgery, and simple comparison of the airway pressures have shown us that the average pressures of CPPV and CPAP in this investigation have been of the same order.

In practice, have the advantages of continuous positive airway pressure breathing been demonstrated? The rise in the arterial oxygen tension during stage $I$ of the investigation has been in part confirmed by other observers (Hatch et al., 1973).

It may however indicate that in our investigation the end-expiratory pressure during CPPV was less than optimal, and further improvements in $\mathrm{PaO}_{2}$ during CPPV may have been obtained by raising the end-expiratory pressure above the 3-5 cm water used (Sykes et al., 1970; Ashbaugh and Petty, 1973) but at the expense of a reduced venous return. This improvement in $\mathrm{PaO}_{2}$ has been related to the mean airway pressure (Cheney and Martin, 1971). However, the arterial oxygen tension not only depends on the pulmonary venous admixture but also on the oxygen content of the admixed venous blood, which in turn is linked with cardiac output.

In stage II of this investigation the fall in $\mathrm{PaO}_{2}$ and increase in measured pulmonary venous admixture occurred within 15 minutes. Our experience indicates that this change would be progressive, and is probably produced by a reduction in the number of ventilated alveoli, and air trapping at the reduced functional residual capacity; Gregory et al. (1971) postulated that the effect of CPAP was to recruit and stabilize alveoli. It was evident in our investigation that on starting 
to breathe at ambient pressure there was often a clinically apparent increase in the work of breathing.

Previous investigators have not suggested at what stage CPAP becomes a suitable alternative to CPPV; our clinical results show that this is so at the time that the cardiovascular system becomes stable. We would suggest that the observations of most value in this respect are peripheral skin temperature (Ross, Brock, and Aynsley-Green 1969), urine flow, and left atrial pressure. The increased respiratory work when positive pressure ventilation is discontinued and CPAP begun may be more than balanced by the occasionally very notable reduction in restlessness.

Our early experience with this technique demonstrated that too high an airway pressure can be attended by a clinically evident fall in cardiac output. The airway pressure to be used should be the minimum which is attended by satisfactory and sustained arterial oxygen tension levels. We recommend a maximum pressure of $8 \mathrm{~cm}$ water, which is reduced progressively as the arterial oxygen tension improves.

The three neonates show some notable differences from the other patients in the series.

It would seem advisable to reduce the deadspace to a minimum in the management of neonates, although clinically the higher carbon dioxide tensions are well tolerated.

We gratefully acknowledge the help received from the Medical Physics Technicians of the Leeds Regional Thoracic Surgical Centre, Messrs. A. Havard, W. N. Martin, and A. Whittaker.

The CPAP apparatus used in this investigation may be obtained from Lusterlite Products, 56 Devon Road, Leeds 2, Yorkshire, England.

\section{REFERENCES}

Ashbaugh, D. G. and Petty, J. L. (1973). Positive endexpiratory pressure; physiology, indications, and contraindications. Journal of Thoracic and Cardiovascular Surgery, 65, 165.

Banerjee, C. K., Girling, D. J., and Wigglesworth, J. S. (1972). Pulmonary fibroplasia in newborn babies treated with oxygen and artificial ventilation. Archives of Diseases in Childhood, 47, 509.

Barnes, N. D., Glover, W. J., Hull, D., and Milner, A. D. (1969). Effects of prolonged positivepressure ventilation in infancy. Lancet, 2, 1096.

Bushman, J. A. and Robinson, J. S. (1968). A 'single' ventilator hose. British Journal of Anaesthesia, 40, 796.
Cheney, F. W. and Martin, W. E. (1971). Effects of continuous positive-pressure ventilation on gas exchange in acute pulmonary edema. Journal of Applied Physiology, 30, 378.

Crew, A. D., Wall, E., and Wright, C. J. (1971). A paediatric nasotracheal tube connection (for use in prolonged nasotracheal intubation and ventilation of neonates). A naesthesia, 26, 372.

Daily, W. J. R. and Northway, W. M. (1971). Perspectives in mechanical ventilation of the newborn. Advances in Pediatrics, Vol. 18, p. 253. Ed. by E. Schulman. Year Book Publishers, Chicago.

Downes, J. J., Nicodemus, H. F., Pierce, W. S., and Waldhausen, J. A. (1970). Acute respiratory failure in infants following cardiovascular surgery. Journal of Thoracic and Cardiovascular Surgery, 59, 21.

Gregory, G. A. (1972). Respiratory care of newborn infants. Pediatric Clinics of North America, 19, 311 .

-, Kitterman, J. A., Phibbs, R. H., Tooley, W. H., and Hamilton, W. K. (1971). Treatment of the idiopathatic respiratory-distress syndrome with continuous positive airway pressure. New England Journal of Medicine, 284, 1333.

Haller, J. A., Donahoo, J. S., White, J. J., Moynihan, P. C., and Galvis, A. G., (1973). Use of continuous positive airway pressure in the improved post-operative management of neonatal respiratory emergencies. Annals of Thoracic Surgery, 15, 607.

Hatch, D. J., Cogswell, J. J., Taylor, B. W., Battersby, E. F., Glover, W. J., and Kerr, A. A. (1973) Continuous positive airway pressure after openheart operations in infancy. Lancet, $2,469$.

Hayes, B. and Robinson, J. S. (1970). An assessment of methods of humidification of inspired gas. British Journal of Anaesthesia, 42, 94.

Howlett, G. (1972). Lung mechanics in normal infants and infants with congenital heart disease. Archives of Diseases of Childhood, 47, 707.

Kelman, G. R. and Nunn, J. F. (1968). Computer Produced Physiological Tables. Butterworth.

Lees, M. H., Burnell, R. H., Morgan, C. L., and Ross, B. B. (1968). Ventilation-perfusion relationships in children with heart disease and diminished pulmonary blood flow. Pediatrics, 42, 778.

, Way, R. C., and Ross, B. B. (1967). Ventilation and respiratory gas transfer of infants with increased pulmonary blood flow. Pediatrics, 40, 259.

Ross, B. A., Brock, R. C., and Aynsley-Green, A. (1969). Observations on central and peripheral temperatures in the understanding and management of shock. British Journal of Surgery, 56, 877.

Sheffer, L., Steffenson, J. L., and Birch, A. A. (1972). Nitrous-oxide-induced diffusion hypoxia in patients breathing spontaneously. Anesthesiology, 37, 436 . 
Stanger, P., Lucas, R. V., Jr, and Edward, J. E. (1969). Anatomic factors causing respiratory distress in acyanotic congenital cardiac disease. Pediatrics, 43, 760.

Stewart, S., Edmunds, L. H., Kirklin, J. W., and Allarde, R. R. (1973). Spontaneous breathing with continuous positive airway pressure after open intracardiac operations in infants. Journal of Thoracic and Cardiovascular Surgery, 65, 37.
Sykes, M. K., Adams, A. P., McCormick, P. W. Bird, B., and Greenburgh, S. (1970). The effect of mechanical ventilation after open-heart surgery. Anaesthesia, 25, 525.

Requests for reprints to: A. D. Crew, F.F.A.R.C.S., Leeds Regional Thoracic Surgical Centre, Killingbeck Hospital, Leeds LS14 6UQ. 